IRSH 6I (2016), Special Issue, pp. 93-I I 4 doi:Io.I I I 7/S00208590 I60005 I I

(C) 2016 Internationaal Instituut voor Sociale Geschiedenis

\title{
Dynamics of Continuity and Change: Shifts in Labour Relations in the Potosí Mines (I680-I8I 2)*
}

\author{
R OsSANA BARRAgÁN Romano \\ International Institute of Social History \\ PO Box 2 I69, I000 CD Amsterdam, The Netherlands
}

E-mail: rba@iisg.nl

\begin{abstract}
Labour relations in the silver mines of Potosí are almost synonymous with the mita, a system of unfree work that lasted from the end of the sixteenth century until the beginning of the nineteenth century. However, behind this continuity there were important changes, but also other forms of work, both free and self-employed. The analysis here is focused on how the "polity" contributed to shape labour relations, especially from the end of the seventeenth century and throughout the eighteenth century. This article scrutinizes the labour policies of the Spanish monarchy on the one hand, which favoured certain economic sectors and regions to ensure revenue, and on the other the initiatives both of mine entrepreneurs and workers - unfree, free, and self-employed - who all contributed to changing the system of labour.
\end{abstract}

The Potosí silver mines are said to have been present at the birth of global trade, which began to grow in the sixteenth century. The mines continued to be exploited until the first few decades of the nineteenth century. ${ }^{\mathrm{I}}$ Throughout that long period, the mines were worked by the indigenous population, most particularly under the system of mita or

\footnotetext{
* This article is based on the Potosí archives in Sucre, and on archives in Buenos Aires and Seville. It also draws on a rich historiography. See R. Barragán, “'Indios Esclavos'. En torno a la mita minera y los servicios personales, I790-1 8 I 2", in Clément Thibaud et al. (eds), Les révolutions des empires Atlantiques. Une perspective transnationale (Paris, 2013); R. Barragán, "Extractive Economy and Institutions? Technology, Labour and Land in Potosí (I6th to I8th Century)”, in Karin Hofmeester and Pim de Zwart (eds), Colonialism, Institutional Change and Shifts in Global Labour Relations (Amsterdam, forthcoming); R. Barragán, "Working Silver for the World: Mining Labor and Popular Economy in Potosí", in Hispanic American Historical Review, (forthcoming). For further historiography, see footnote 2.

I. After the decline of silver, at the end of the nineteenth century, Potosís mountain produced tin, and since the last few decades of the twentieth century it has produced zinc, lead, tin, and silver (again).
} 
unfree work, which was established in the final decades of the sixteenth century and remained in place until it was abolished in $18 \mathrm{I} 2 .{ }^{2}$ Behind the continuity of the mita lay important changes that will be examined in this article. It will look, too, at other forms of work, both free and selfemployed. The analysis is focused on how the "polity" could shape labour relations, especially from the end of the seventeenth century (I680) and throughout the eighteenth century. The role of the state as conqueror in early times, as employer more recently, and as redistributor over the past few centuries has been pointed out by the editors of this Special Issue. This article scrutinizes both the labour policies of the Spanish monarchy, which favoured certain economic sectors and regions to ensure revenue and the initiatives of mine entrepreneurs and workers, who contributed to changing the system of labour.

My point of departure was to think about the complexities of what the "state" is. ${ }^{3}$ In contrast to the concept of a well-defined and identified institution, over the past decade academics have criticized the notion of a geographical and political centre of power conceived as one entity with a single coherent policy, and any clear distinction between the state and civil society. The approach taken here is to consider the state as an ensemble of political and administrative levels interconnected through policies and practices. Those policies and practices are conceived of as the result of conflicts and struggles between different actors, groups, and regions, generating a dynamic with often unpredictable consequences.

2. The classic studies of Potosí and Indian labour remain Alberto Crespo Rodas, "La 'mita' de Potosi", Revista Histórica, 22 (1955-1956), pp. 169-182; Peter Bakewell, Miners of the Red Mountain: Indian Labor in Potosi, I545-I650 (Albuquerque, NM, I984); Jeffrey Cole, The Potosi Mita, I573-1700: Compulsory Indian Labor in the Andes (Stanford, CA, 1985) for the early periods; and Rose Marie Buechler, Gobierno, Minería y Sociedad. Potosi y el "Renacimiento" Borbónico, I776-I8I0 (La Paz, I989); Enrique Tandeter, "Forced and Free Labour in Late Colonial Potosí", Past and Present, 93 (1981), pp. 98-136; and idem, Coacción y Mercado. La minería de la plata en el Potosí colonial, I692-I 826 (Buenos Aires, I992) for the later periods.

3. Scholars have differentiated between a political-legal organization, a collection of instruments and institutions, and a state system, on the one hand, and the construction of consensus and hegemony, the functions of cohesion and unification, the ideological project, and the "idea of the state" or imaginary unity, on the other. See Philip Abrams, "Notes on the Difficulty of Studying the State (1977)"; Journal of Historical Sociology, I:I (1988); Philip Corrigan, "State Formation", in Gilbert M. Joseph and Daniel Nugent (eds), Everyday Forms of State Formation: Revolution and the Negotiation of Rule in Modern Mexico (Durham, NC, and London, I994), pp. xvii-xxi; Martin Smith, Power and the State (Basingstoke, 2009); Bob Jessop, "From Micro-Powers to Governmentality: Foucault's Work on Statehood, State Formation, Statecraft and State Power", Political Geography, 26: I (2007), pp. 34-40. Sharma and Gupta wrote that instead of viewing states as preconstituted institutions that perform given functions, they are produced through everyday practices: Aradhana Sharma and Akhil Gupta (eds), The Anthropology of the State (Oxford, 2006), p. 27. 
The first part of this article summarizes my view of the main labour relations and their shifts over four periods from i 545 to I 8 I 2 . After an initial period of exploitation, based mainly on a system of sharecropping, mita or unfree labour was established in I574-I575 during the second period and coexisted with free minga labour. Through the years, mita changed along with the whole labour system, and I shall describe its main characteristics and shifts. With this panorama, which complements the contribution by Raquel Gil Montero and Paula Zagalsky in the present Special Issue, this article focuses on the struggles to widen or abolish mita unleashed almost a hundred years after its implementation (I680-I732). Here, my analysis centres on the interaction between the authorities at different levels within the Spanish monarchy.

The second part of the article draws on the debates that took place within the different levels of the state, while the third examines workers' initiatives in response to developments in state policy that influenced the entirety of labour relations. In the eighteenth century, self-employed workers or kajchas emerged and consolidated their position in close association with rudimentary ore-grinding mills, called trapiches, where silver was refined. The peculiarity of the eighteenth century lies in the fact that the main sources reveal that both unfree mitayos and free mingas could have been the same self-employed workers. That means that workers' control over production and processing was growing, and explains why coerced labour could not be transformed either into completely free labour, or into completely unfree labour. The result was a combination of different settings in which labour fell into distinct categories, but this did not mean that there were necessarily always distinct groups of workers.

Finally, in the fourth part, I shall analyse a new wave of discussion dealing with the right of the Crown to favour the Potosí mines and their tenants as if they formed part of the state public sector. That was a significant debate and should be placed in the general context of the projects and reforms of the monarchy in the eighteenth century and changes in the political process from I 808-I 8 I 2 that led to the disintegration of the Spanish Empire. ${ }^{4}$ The debate involved functionaries in different administrative and political layers of the economic and political establishment. As we shall see in more detail in

4. The political crisis started with the conflicts linked to Napoleon Bonaparte, who invaded Portugal (1807) and Spain (1808). Charles IV, King of Spain, abdicated in favour of his son Ferdinand VII, who was overthrown by Napoleon. Spain was subsequently entrusted to Joseph Bonaparte. In May I 809, a rebellion broke out in Madrid against the French occupation. Local and regional assemblies were organized (juntas) in favour of the Spanish king. The same happened in the Americas. A central junta then convened an Extraordinary and General Assembly, or Cortes de Cádiz, which promulgated the first Spanish Constitution in I 8 I 2. In the Spanish Americas, the crisis led to a series of struggles, particularly after $18 \mathrm{I} 4$, which ended with the political independence of most of South America. 
the last part of this article, this included the mine owners and mercury millers (azogueros) of Potosí, the authorities in the cities, and the judicial and religious authorities of the Audiencia de Charcas (see Figures 2 and 3 ). One of the highest authorities of the audiencia questioned the general assumption that silver was the "blood of the political body". 5 The discussion undermined the legitimacy not only of the authorities, but also of the mita, because it was a burning issue over a large geographical area and had consequences for the next twenty years until its formal abolition in I 8 I 2 in the Cortes de Cádiz that gave Spain its first constitution. In the process, the mita became a symbol of inequality, oppression, and of a system of labour associated with the ancien régime and the conquest of America.

\section{SILVER PRODUCTION AND THE MAIN SHIFTS IN LABOUR RELATIONSHIPS IN POTOSÍ, 1545-1812}

The Potosí mines were "discovered" in I 545 and very quickly began to be exploited for the benefit of the Spanish Crown. Legislation maintained the legal doctrine of royal ownership of the subsoil, allowing it to be exploited by individuals in exchange for a tax on what they produced. In principle, the king granted rights to his vassals and subjects, whatever their status. However, with some exceptions, the indigenous people did not own the seams of Potosî's mines and became workers. ${ }^{6}$

Production figures for Potosí (Figure I), as reconstructed by Garner and $\mathrm{TePaske}^{7}$ and based on the royal tax levied on the production of silver pesos, ${ }^{8}$ shows a spectacular boom between I 549 and I605, a decline during the seventeenth century, and then recovery between 1724 and 1790.9

5. "Discurso", in Ricardo Levene, Vida y Escritos de Victorian de Villaba (Buenos Aires, 1946), p. xxxi.

6. For an analysis of property in mines and on land, see Barragán, "Extractive Economy and Institutions?”.

7. The main evaluations come from the work of John TePaske and Herbert Klein, The Royal Treasuries of the Spanish Empire in America, 3 vols (Durham, NC, 1982). Those accounts are published on the website of Richard Garner, available at www.insidemydesk.com, (last accessed 26 August 2016. See also Richard Garner, "Long-Term Silver Mining Trends in Spanish America: A Comparative Analysis of Peru and Mexico", The American Historical Review, 93:4 (1988), pp. 898-935; John TePaske, A New World of Gold and Silver (Leiden, 2010); and idem, "New World Silver, Castile and the Philippines, I 590-I 800 ", in J. Richards (ed.), Precious Metals in the Later Medieval and Early Modern Worlds (Durham, NC, 1983).

8. The high-quality eight-real coin, also known as the Spanish dollar due to its wide circulation in the period.

9. The royal taxes (twenty per cent of production in Potosí) are converted into pesos (value in pesos). On the peso, see Carlos Marichal, "The Spanish-American Silver Peso: Export Commodity and Global Money of the Ancien Regime, I 550-1 800", in Steven Topik, Carlos Marichal, and Zephyr Frank (eds), From Silver to Cocaine: Latin American Commodity Chains and the Building of the World Economy, I500-2000 (Durham, NC, 2000), pp. 25-52. For the general 


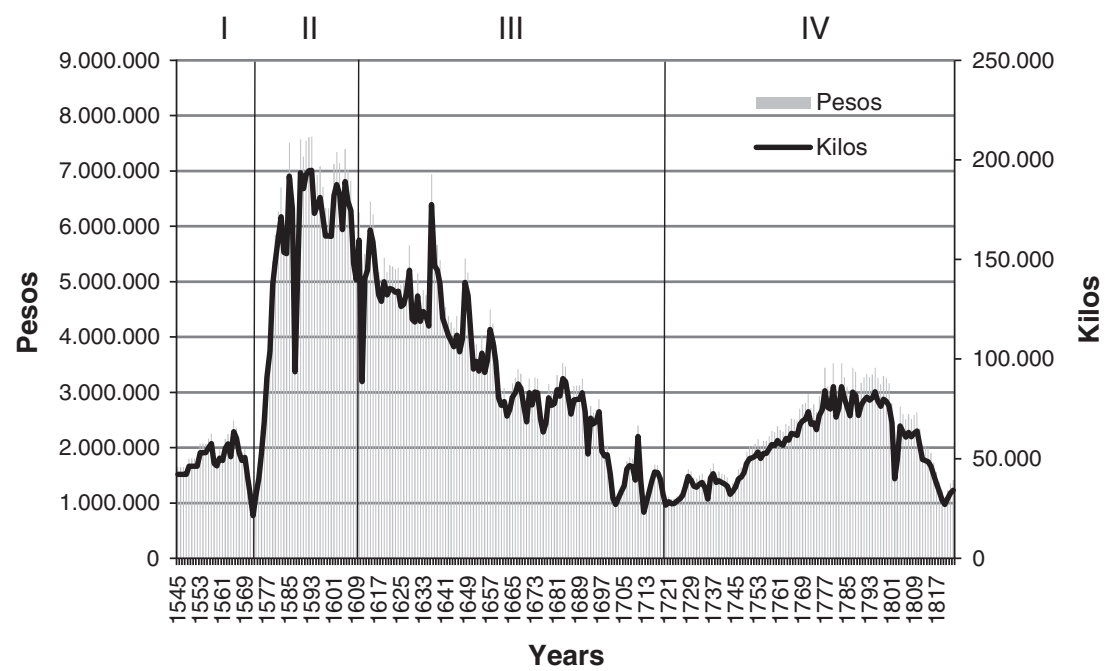

I: Share-cropping

II: Unfree and Free Labour (Mita-Minga)

III: Unfree and Free Labour (Mita-Minga), part of the mita labour transformed into a monetary tax

IV: Unfree and Free Labour (Mita-Minga), emergence of self-employed workers (kajchas)

Figure I. Silver production in Potosí (I545-18 I7) and the main forms of labour relations Source: Garner Peru sheets, based on TePaske, available at www.insidemydesk.com. The labour relations have been added by me. The vertical axis to the left gives the value of silver in pesos. See footnotes 7,8 , and 9 .

As we shall see, those trends are related mainly to the richness of the ores and to labour policies.

In terms of labour relationships, I distinguish four periods. The first runs from the Spanish discovery of the mines until i 573-I 575. Then, Viceroy Francisco de Toledo instituted the mita system, which began the second period, when Potosí reached its apogee. The third of these periods runs from I610 to 1720 , when production decreased for many reasons, chief

trends emanating from America and the circulation of silver around the world, see Dennis Flynn and Arturo Giráldez, "Cycles of Silver: Global Economic Unity through the Mid-Eighteenth Century", Journal of World History, I3:2 (2002), pp. 391-427; Arturo Giráldez, "Born with a Silver Spoon: China, American Silver and Global Markets during the Early Modern Period" (Ph.D. dissertation, University of Amsterdam, 2002); Richard Garner, "Where Did all the Silver Go? Bullion Outflows 1570-1650: A Review of the Numbers and the Absence of Numbers", October 2006, available at www.insidemydesk.com/lapubs/NetDraft-SilverGoRev.pdf, (last accessed 26 August 2016). About the revival in the eighteenth century, Garner wrote: "Without Potosi's eighteenth-century revival, both the mining economy and the general economy might have remained stalled down to the end of the colonial period" (Garner, "Long-Term Silver Mining Trends", pp. 910-9II). For Tandeter, the revival was between I73I and I800. Even with a diminished role towards the I770s, Potosí accounted for forty per cent of the silver originating from the Viceroyalty of Peru. Tandeter, "Forced and Free Labour", p. Io०. 
among which were the impoverishment of the ores and a shortage of labour. Over those one hundred years the mita system "metamorphosed", with corvée labour changing to cash payments as production declined. Finally, the fourth period was marked by a renaissance in the production of silver in Potosí after 1720. Although that rise in production appears small in comparison with the first, it was, nevertheless, important. Output of silver rose, partly because in 1736 the tax on silver was reduced from a fifth to a tenth of its value, but also because of the additional mercury supplied from Almaden ${ }^{10}$ and as a result of a consolidation of the activities of self-employed workers, or kajchas.

Let us analyse this overview in more detail. In the first period, the extraction process, smelting, and casting in wind-blown furnaces (a traditional pre-Hispanic technique called huayras), and the sale of the silver in local markets were all controlled by the indigenous population. They carried out the extraction using their own means of production, exploiting part of the mines at their own cost and largely for their own benefit. It was a system of sharecropping, or a kind of leasing of property. ${ }^{\text {II }}$

Figure I shows an astonishing increase in production after I 575. The period was marked by the rule of Viceroy Francisco de Toledo, who, in the I 570 s, organized the "colonial system", ${ }^{\mathrm{I} 2}$ which involved re-launching mining from Potosí (due to the scarcity of high-grade metals), introducing technological changes and the mita as a method of continuous provision of labour. The amalgamation process, in which pulverized ore was blended with mercury, required the provision of mercury from the Huancavelica mine in Peru, water for the refining mills, and an important contingent of manpower - through the mita system.

The institution consisted of a constant supply of labour based on the pre-Hispanic system of work, the mita, meaning "turn". Toledo organized the system, which involved an Indian labour force of I 4,000 men between eighteen and fifty years of age being recruited from seventeen provinces to work in Potosí, taking their families with them. They worked in Potosís mines and mills for a year under the leadership of local Indian authorities (caciques, or curacas).

The mita workers (draft labour) were therefore one part of Potosís labour system, while the minga workers made up the rest. Insofar as the mita were considered unfree labour, the mingas can be considered free labour. However, my recent research has led me to conclude that instead of two separate and opposed categories, we should think in terms of a single system of work, the mita-minga system, which I found applies particularly

ıо. TePaske, A New World of Gold And Silver, p. I46.

I I. Carlos Sempat Assadourian, El Sistema de la Economía Colonial. Mercado Interno, Regiones y Espacio Económico (Lima, 1982), pp. 22 and 295; Bakewell, Miners of the Red Mountain, p. 5 I. I2. Sempat Assadourian, El Sistema de la Economía Colonial. 
to the eighteenth century. To understand that, we must remember that every year the total number of mitayo or unfree workers was divided into three contingents of labourers. The contingent not working were considered to be in "buelga", or "on strike", indicating that they were effectively on leave. Turns of work alternated each week so that, in principle, everyone worked for one week and "rested" (in "buelga") for two weeks. The mitayos then had to work seventeen weeks or four non-consecutive months, which they did throughout the year. Some sources indicate that the free workers, or mingas, were recruited precisely from among men who were "de buelga", in other words the mitayos. ${ }^{13}$ If that was so, then the mingas were, on the whole, the same people as the mitayos.

Mitayos (corvee, or unfree workers) and minga workers (paid by the day, or free workers) were present from the sixteenth to the eighteenth centuries, but the continuity of terms for workers can obscure changes that began in the first few decades of the seventeenth century, when some workers avoided unfree mita work by transforming their obligation to work into a payment in cash, a process generally channelled through their authorities (caciques). During that third period, what Cole has called a metamorphosis of the mita took place. ${ }^{\mathrm{I}}$ The money paid by the workers through their own native authorities could be used by the mine and mill owners to employ free labour or minga workers, but in some cases they simply kept it for themselves.

During the seventeenth century, an enormous amount of regional migration occurred as people from communities obliged to send mita workers decamped to other provinces ${ }^{15}$ where they were not registered or where they would not be liable to mita service. The result of all these changes explains why the number of mitayo workers declined from the i4,000 established by Toledo in I 573-1575 to no more than 4,000 by the end of the seventeenth century. That was a fall in excess of seventy per cent, and in the eighteenth century the number declined even further to approximately $3,000{ }^{16}$

In the fourth period, from about $\mathrm{I} 730$, an upturn in mining activity meant cash payments from workers became less important. Now, the most important feature was the emergence of kajchas, who, as far as mine owners were concerned, were simply thieves who stole ore during the weekends. The self-employed kajchas undoubtedly challenged and questioned the

13. Cole, The Potosi Mita, pp. 9, I 2, I4.

I4. Ibid., pp. 23-45.

i s. See Nicolás Sánchez-Albornoz, Indios y Tributos en el Alto Perú (Lima, 1978); Sempat Assadourian, El Sistema de la Economía Colonial; Thierry Saignes, Caciques, Tribute and Migration in the Southern Andes: Indian Society and the I7th Century Colonial Order (London, 1985). There followed a far-reaching redistribution of the Andean population, which took place largely in the seventeenth century.

I6. There were, nevertheless, only 3,199 mitayos workers each year, instead of 17,000 (Decree of Viceroy Castelfuerte, 1736; Tandeter, "Forced and Free Labour”, pp. I02-103). 
ownership and the exploitation of the ores, as the kajchas exploited them by processing them in their own rudimentary mills or trapiches (Figure 4 ). The combination of mitayo and minga workers, as well as that of kajchas and trapiches, was characteristic of the eighteenth century.

In I 8 I 2, the first national legislative assembly took place in Cadiz, which, as a result of the French occupation of Spain by Napoleon, claimed to represent the whole of the peninsula and Spanish territory in America. Cadiz therefore represents a climactic point in the political crisis that began in I 808, and scholars have highlighted the political revolution that put an end to the ancien régime. The Assembly of the Cortes de Cádiz formally ended the mita system.

This overview shows that among the most important changes was the switch from corvée labour to payment in cash and a constant reduction of the number of workers going to Potosí, which led to endless complaints and requests by the mine and mill owners. There was also significant discussion of the situation among the authorities.

THE DEBATES ON WHETHER TO EXTEND OR ABOLISH THE MITA (1680-1735): BETWEEN POTOSÍ, LIMA, SEVILLE, AND MADRID

The continuous drop in the number of workers going to Potosí and the changes introduced led to intense debates about reforming Potosís mining industry. The owners pushed for a new allocation of labour for the mita, while various members of the bureaucracy opposed their request, considering them a group operating in a region privileged by state policies. I propose to distinguish two phases in the struggle, the first occurring between I 689 and I700 and the second between I7IO and I735. In both of them it is fascinating to analyse the requests of Potosís guild of mine and mill owners (azogueros). ${ }^{17}$

A first request was made in the form of a petition submitted by representatives of Potosís mine and mill owners to the Consejo de Indias, Madrid, $1633 .{ }^{18}$ It is important to note that the mine and mill owners claim to be speaking on behalf of the whole city (Villa Imperial de Potosí). The first paragraph of the petition recalls the importance of the discovery of Peru for the monarchy, for the Empire, and for Spain, and refers to the imperial city of Potosí. The three main measures were for taxes to be reduced (from twenty per cent to ten per cent); a new census to be held, and labour reallocated; and a better distribution of mercury or azogue.

17. The name comes from azogue, mercury, used to produce silver by amalgamation.

I8. Pretensiones de la Villa Imperial de Potosi propuestas en el Real Consejo de las Indias (Madrid, I633). 
Most interesting is the interaction between the different levels of the public administration: the intervention by members of the audiencias of Lima and Charcas, by the Viceroy of Peru, ${ }^{19}$ and by the Consejo de Indias in Spain (Figures 2 and 3). It is clear that opinions on the matter were expressed at all levels, and the abolition of the mita system was one option discussed. The highest Spanish authorities tried to sustain a policy of equilibrium, which explains the continuation of the mita, for though they did not permit its expansion, they did not support its abolition either.

Scrutinizing the procedures and decisions in both phases allows some conclusions. First, it is evident that consecutive viceroys from Peru (Melchor de Navarra, Duke of Palata, I68I-I689; and Melchor Portocarrero, Count of Monclova, I689-1705) sometimes had different or even opposing labour policies in relation to Potosí. This is not to say that the authorities in Spain did not take a consistent position regarding support for or the abolition of the mita. The reality "on the ground", though, was that the implementation of state policy was mediated through conflicts and struggles of different groups and sectors, leading to unpredictable consequences. Second, the debates were referred to Spain, where members of the Consejo de Indias intervened to take a decision. Third, Potosís mine and mill owners' guild sent its own representatives to Spain, and their arguments, too, were crucial. Fourth, it is true that, at first glance, the decisions taken do not seem to have changed the labour system radically, although they were the result of negotiations between antagonistic points of view. None of the positions stated predominated, although, while unable to impose its own preference, the mining industry led by the mine and mill owners' guild did succeed in blocking proposals to abolish the mita, which continued albeit on a smaller scale and with some changes.

The first phase in the debate developed after failure of the great reforms that the Viceroy the Duke of Palata had tried to implement in I689. He organized a new census to cover a vast region in order to revise the number of mitayos that every village and province was obliged to provide to Potosí. The census was to include the migrant population (forasteros), who had appeared after the previous census of I 575 . The idea was to reinvigorate the mita by raising its number from 3,000-4,000 workers to the I 2,000-I 4,000 workers of I 575 . The reform also sought to impose tighter fiscal control.

19. The Viceroyalty of Peru, created in 1542 , had jurisdiction over most of Spanish South America. Its capital was Lima. The viceroy represented the King of Spain and his immense territory was divided into a number of andiencias. The andiencias were the supreme tribunal courts, but they also had some legislative and government responsibilities. Two of the most important were the Audiencia de Lima, created in I 543, and the Audiencia Cancillería Real de La Plata de los Charcas, established in I 599 in La Plata (modern-day Sucre), containing an important part of what is now Bolivia. Potosí was in the Audiencia of Charcas. 


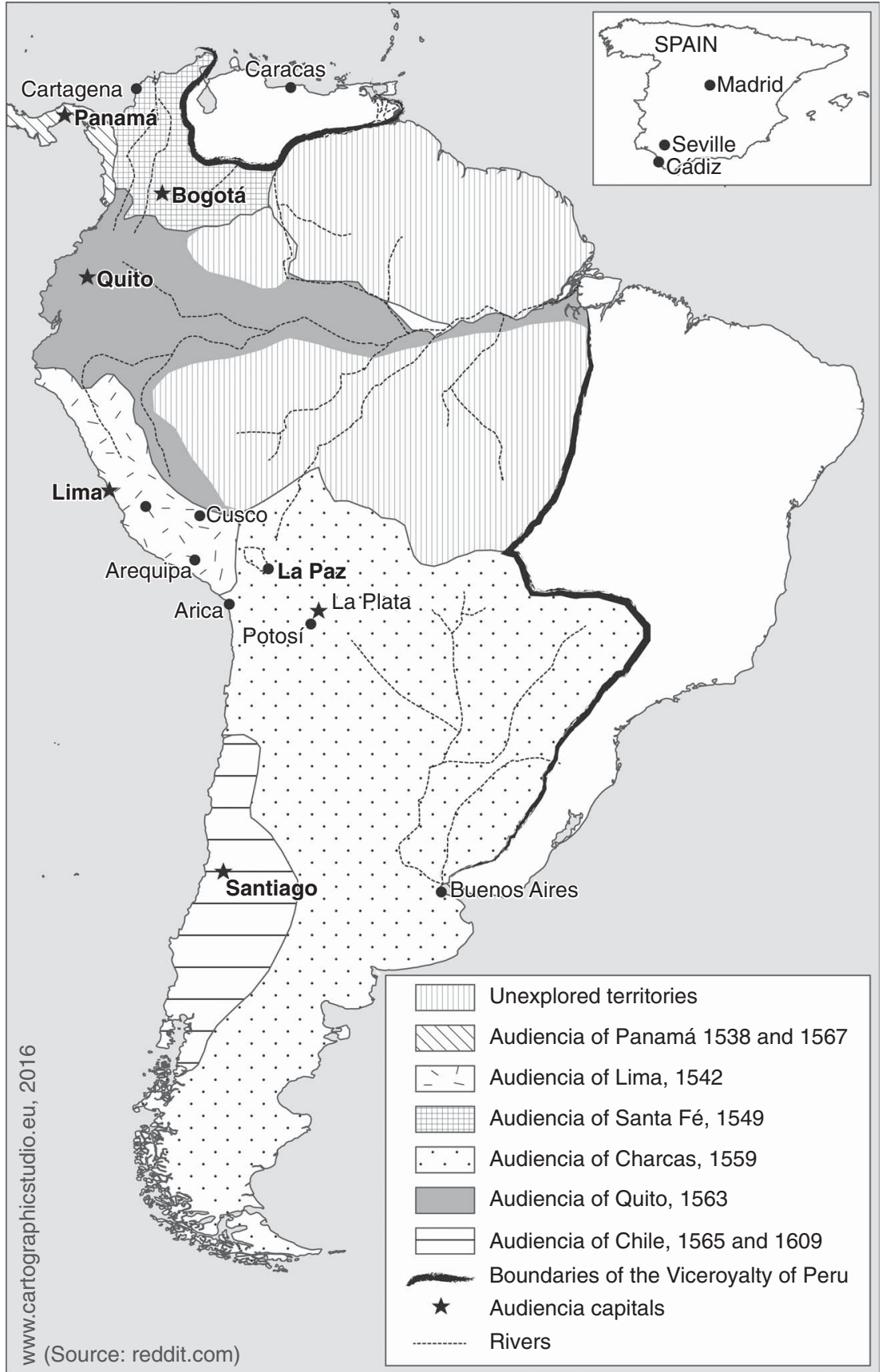

Figure 2. The Viceroyalty of Peru showing the Audiencia de Lima and the Audiencia Cancillería Real de La Plata de los Charcas, c.r650.

Source: http://homepages.udayton.edu/ santamjc/Caribbeanı.html. 


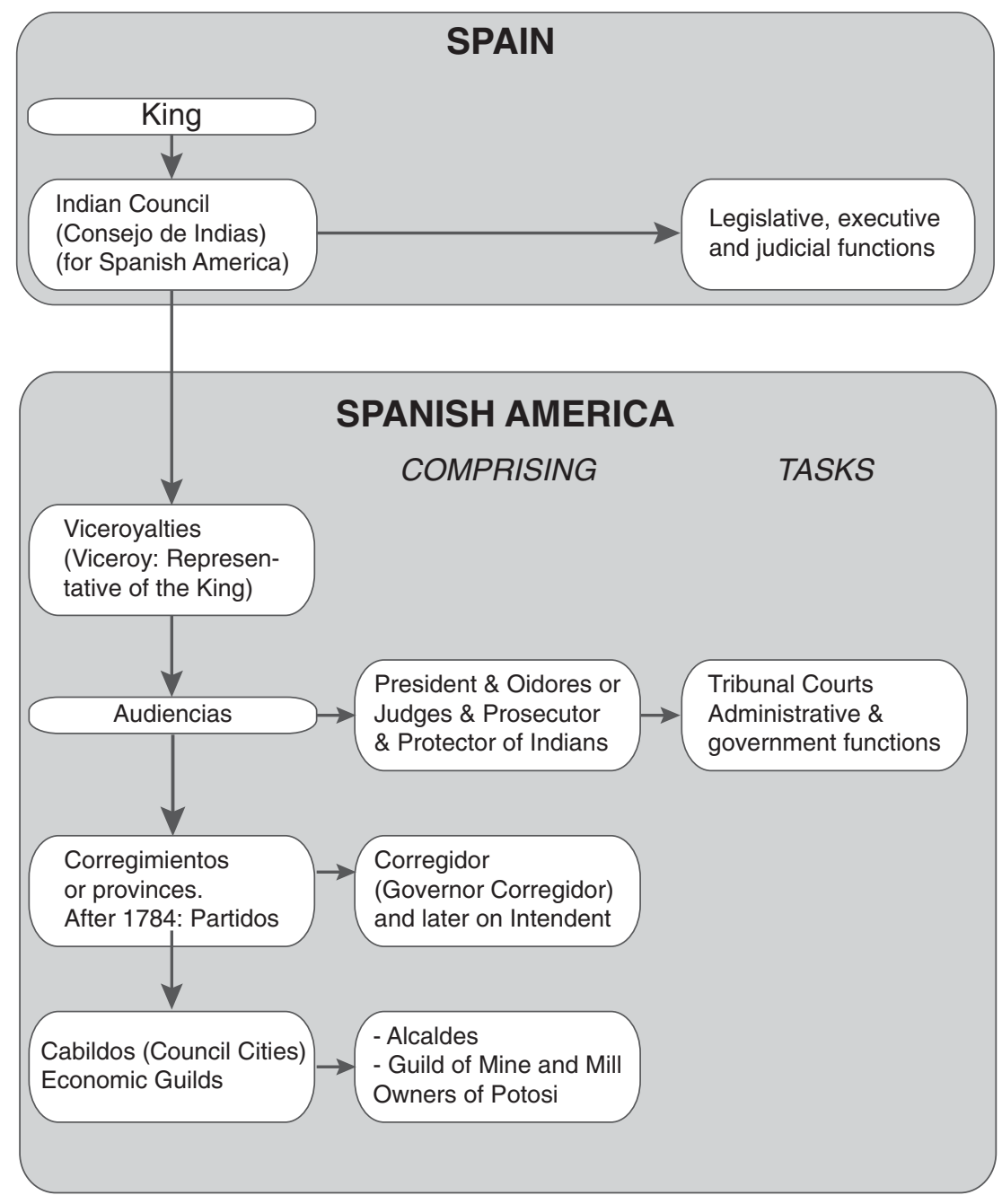

Figure 3. The political levels of authority in Colonial Spanish America Source: Diagram prepared by the author.

His successor as viceroy, Monclova, adopted a completely different policy. He organized a council in I69I, attended by various authorities of the Viceroyalty of Peru, for the purpose of analysing the situation. This they did for almost fifteenth months, until finally two positions emerged. There were those who pleaded for the mita system to be abolished and those who wished it to be continued.

Initially, the first group, in favour of abolishing the mita, predominated. The mita was considered a form of extortion because it had changed from 
corvée labour to payment in cash - which favoured owners - with the complicity of a number of authorities. This position explained the reduction in tax revenues from silver going to the Royal Treasury (Real Hacienda) as systematic fiscal fraud, a result not only of the weakening of the monarchy's economic and political control, but also of the over-exploitation of indigenous labour. ${ }^{20}$ It was at that time that Matías Lagunez, the Prosecutor, or Fiscal, of the Audiencia de Lima, wrote his Discurso sobre la mita. For him, there were two mitas, the one that had been legally sanctioned and the other that was actually practised. ${ }^{2 \mathrm{I}}$ Constant violation of the existing law made the operative mita illegal, and Lagunez also held that there was a network of actors, including indigenous authorities, who were involved in the abuse of indigenous labour for their own purposes. It was Lagunez, too, who developed the important idea that the mining industry was being subsidized $^{22}$ by the low salaries of the mitayos ${ }^{23}$ and that the Potosí mining centre would be unable to survive if it were forced to pay everyone wages as high as those of the free workers or mingas. There was, then, a conviction that the era of unlimited wealth for Potosí had come to an end, but that it was not true that without the mita (Indians) and Potosís wealth Peru itself would not exist. ${ }^{24}$

The competing position took the form of decisive support for mining that basically meant ensuring the best conditions for the sector so that tax revenues would not be endangered. That meant ensuring the flow of and convenient prices for the azogue, or mercury, but also necessitated a sustained supply of mita workers. From that viewpoint, if Potosí failed, everything would be lost: "the Indies would end" and this "would be felt throughout the world". ${ }^{25}$

The result was a juste milien (middle way). It was decided not to increase the number of workers for the mita and not to extend it to new regions or to include new peoples (migrants or forasteros) as the Duke of Palata had planned. However, a royal decree issued in Lima in 1692 established a new allocation of workers to just thirty-four mills (leaving twenty-four mills without workers), although their numbers were set at just 4, I08 in total or I, 367 per week. ${ }^{26}$ However, the guild of the azogueros was able to reduce workers' wages. ${ }^{27}$

20. See Ignacio González Casasnovas, Las dudas de la Corona. La política de repartimientos para la minería de Potosí (Madrid, 2000), p. 270.

21. Ibid., pp. 260, 271, 282-283 and 292.

22. The term used was "saving" money.

23. González Casasnovas, Las dudas de la Corona.

24. Ibid., pp. 337, 400.

25. Ibid., pp. 336-337.

26. Ibid., pp. 318-319 and 367 .

27. Ibid., pp. 325 and 327 . 
The documents were duly analysed in Madrid in I $694 .{ }^{28}$ The Consejo de Indias and other administrative bodies decided that the mita should continue but with certain restrictions. A Royal Decree of I697 (I 8-II) confirmed the measures introduced in 1692 but ordered the addition of four new points: (i) the wages of unfree workers (mitayos) and free workers (mingas) were to be equalized, (ii) commutation of work for payment in cash was to be forbidden; (iii) the fixed amount in ores required from workers was to be reduced; and (iv) the costs incurred by workers in travelling to Potosí should be paid in advance. Some authorities in the audiencias of Lima and La Plata, along with the Archbishop of La Plata, and the mine and mill owners (azogueros) rejected the measure. ${ }^{29}$ Equalizing wages was one of the more controversial points. Some people believed it was intended to conceal the desired end of the mita.

In the second phase of the debate, the contraction in silver production at Potosí was drastic. It was no accident that four requests (memorials) were presented by the mine and mill owners between I708 and I7I4. In I7I9 they opened a debate, once again, about the mita. There were more reports in the 1730 s, which culminated in measures taken in $1735-1736$ that lasted until the end of the eighteenth century.

Particularly in 1709-1710, the mine and mill owners reiterated old requests, namely that the price of mercury be lowered, that royal taxes be reduced, and that there be a new allocation of workers. The owners demanded more effective intervention by the audiencia to guarantee the number of workers allocated, and complained about the corregidores, the regional authorities of the provinces, whom the owners saw as mainly responsible for the diversion of Indian labour for use in other enterprises and businesses. In I7 I4, the owners demanded a ban on the conversion of corvée labour into cash payment, a practice that the owners said was against their own interests. They also wished to reduce the two weeks of rest enjoyed by the mitayos to just one week because they could then engage the same mitayos as free labourers for just one week instead of having to do so for two. ${ }^{30}$ Finally, they claimed that a fifty-quintal box of ore cost one hundred pesos, but they obtained just fourteen quintal of silver from it, for which they were paid only ninety-one pesos. ${ }^{3 \mathrm{I}}$

In I7I9, the Consejo de Indias in Spain examined a file entitled "Considerations concerning the abolition of the forced labour of the mita". The arguments in favour of abolition included the deterioration in Potosís mines, decreased tax revenues, and the negative consequences of forced

3I. Silvio Zavala, El servicio personal de los indios en el Perú, extractos del siglo XVIII, 3 vols (Mexico, I980), III, p. 34 . 
labour for the indigenous population. Three main measures were proposed, namely the abolition of the mita, a reduction in the price of mercury (azogue), and tax cuts. ${ }^{32}$ In the event, the region was hit by a major epidemic, which somehow paralysed the decision-making process.

Later, in 1727 , the azogueros again requested the abrogation of the 1697 measure, particularly the requirement to equalize wages between unfree and free workers. There followed a lockout in Potosí. ${ }^{33}$ Subsequently, a total of nine reports were written in the 1730 s by the magistrates of the Audiencia de Lima and the Audiencia de Charcas. Two ideas coalesced: the "common utility" or the public good for the political body of the kingdom, and the recruitment of free workers during the weeks of rest enjoyed by the unfree mitayos, ${ }^{34}$ the general view being that the allocation of mitayos or unfree labour was inevitable. The main argument of one such report was that such political subordination was not contrary to Christian liberty, that it was one thing to serve, but a completely different thing to be a serf. The Viceroy of Lima sent the votes of the assembly of the magistrates to Spain; most of those magistrates agreed with the mita, ${ }^{35}$ whereupon a new royal decree was issued in Seville in 1732 ordering the continuation of the mita, though calls to equalize the wages for unfree labour and free labour were set aside. The one week of work and two weeks of rest of the mitayos was reconfirmed and Indian migrants (forasteros) were included among the mita workers. $^{36}$

Clearly, the preferred option of the mine and mill owners that their allocation should revert to approximately I 4,000 workers instead of 4,000a demand they had also submitted to the Viceroy the Duke of Palata - was no longer feasible. However, at least the threat of abolishing the mita never materialized either. The long-awaited demand that taxes be reduced from twenty per cent to ten per cent promulgated by royal decree on 28 January $1735^{37}$ seems to have been introduced to compensate the persistence of the mine and mill owners, and in response to the reduced purity of the ore in Potosí.

\section{THE WORKERS INITIATIVES: THE SELF-EMPLOYED KAJCHAS AND TRAPICHES}

It is certain that one of the most relevant changes in the eighteenth century was the emergence of kajchas, who were associated with the rudimentary

32. González Casasnovas, Las dudas de la Corona, p. 406.

33. Zavala, El servicio personal de los indios en el Perú, III, pp. 35-36.

34. González Casasnovas, Las dudas de la Corona, p. 430 and 434.

35. Zavala, El servicio personal de los indios en el Perú, III, pp. I9 and 23, $3 \mathrm{I}$.

36. Ibid., pp. 32-33, and González Casasnovas, Las dudas de la Corona, pp. 44I-442.

37. Zavala, El servicio personal de los indios en el Perú, III, p. 36. 
ore-grinding mills called trapiches. They were self-employed workers, according to the taxonomy of the Global Collaboratory on the History of Labour Relations of the International Institute of Social History (IISH).

The owners of the mines called the kajchas the "weekend thieves", but the tradition of fairly free access to the ores had existed since the first few decades of Potosís mine exploitation. Viceroy Toledo, who established the mita and the amalgamation process, himself stated in the legal regulations he drew up that the owners of the mines were obliged to give the workers a quarter of the mines as "had been done until then", on condition that they sell the metals they obtained back to the owners of the mines and refineries. ${ }^{38}$ It is possible that such indulgence shown to the indigenous population working on the Cerro de Potosí was considered some sort of compensation and actually originated as the natives began to be denied free access to the ore. What might have looked like a concession had therefore become established as a right, whose origins had been largely lost in the mists of time. The existence of the kajchas meant therefore that neither ownership of the mines, nor the exclusive property rights of the Spanish mine owners were entirely accepted by the workers, who, for their part, insisted on their own rights of access to the silver mines, such as they had had since early times. Similarly, although deprived of actual ownership of the mines, as kajchas the mita and minga workers nevertheless maintained control over a substantial portion of the ore.

The kajchas exploited the ore, and the role of the trapicheros was to refine it. In I759, a trapiche (Figure 4) was described as the place where the ore was ground, which was done using large rocks ${ }^{39}$ rather than the sophisticated machinery of a trituration mill or the water mill of the ingenio used for refining. In the trapiches, after ore had been crushed, the powder was mixed with mercury, salt, and sometimes tin. The ore was then washed to create a silver/mercury amalgam, which settled in the water. The amalgam could be sold as it was, directly to the dealers, or it could be "burned" to obtain pure silver that could then be sold to the bank established by the Spanish Crown. ${ }^{40}$

The sources reveal the growing strength of the kajchas and trapiches from 1750 onwards. One of the most interesting aspects of a $176 \mathrm{I}-1762$ report is

38. "Ordenanza X", in Relaciones de los Vireyes y audiencias que han gobernado el Perú, Vol. I: Memorial y Ordenanzas de D. Francisco de Toledo (Lima, i 867), p. 357.

39. The trapiche consisted of stones to grind the ore and one or two cochas or small ponds to wash it.

40. See "Testimonio de la visita de cerro yngenios y trapiches del cerro rico y ribera de la imperial Villa de Potosi con expresion de los nombres de las minas, sus varas, rumbos y frontis [...] 1789-1790", Charcas 700, fol. I 23v.-24, Archivo General de Indias de Sevilla [hereafter, AGI]. 


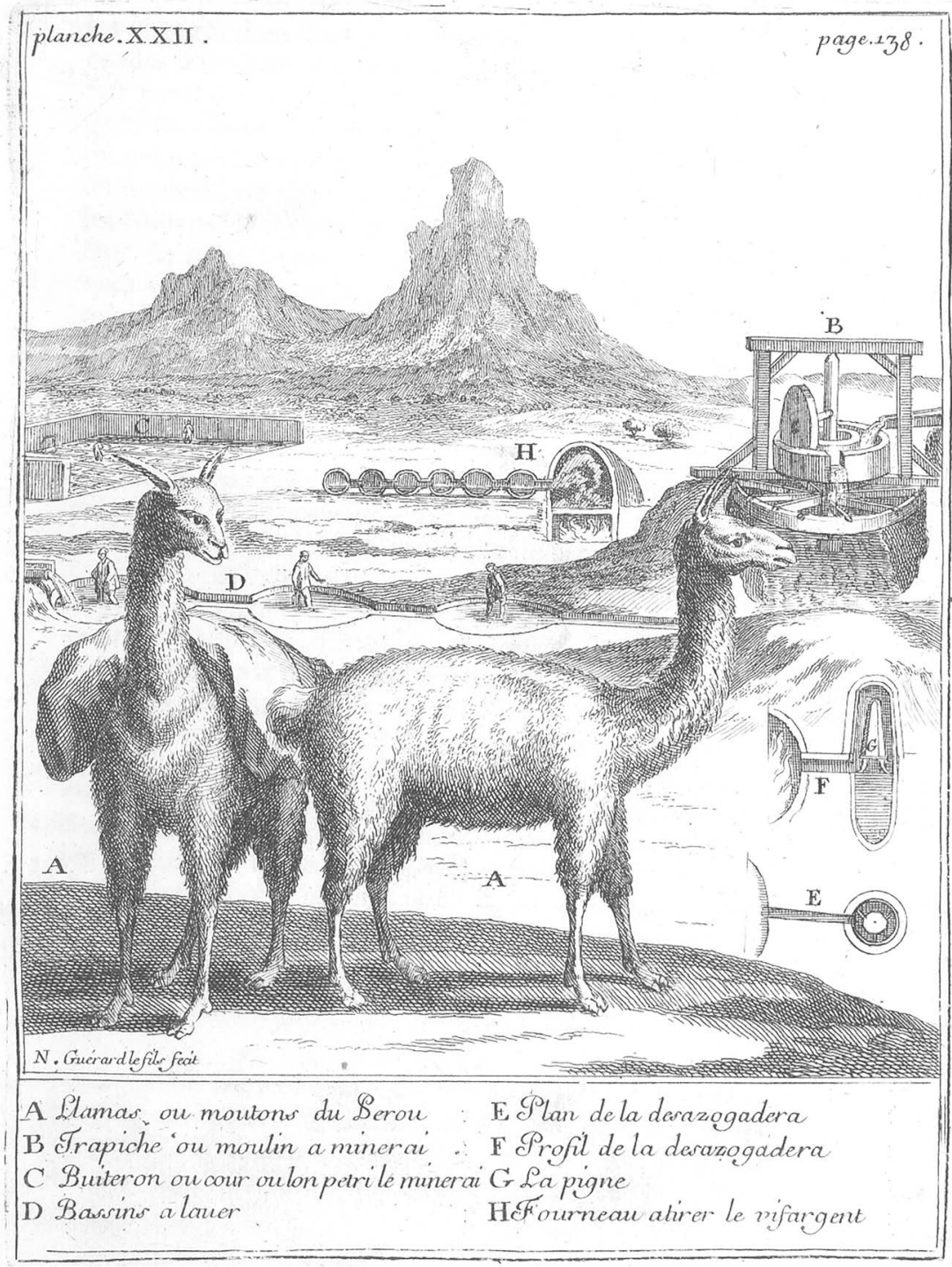

Figure 4. Trapiche according to Frézier, 1732. $\mathrm{B}=$ Trapiche mill to crush minerals. $\mathrm{D}=$ Ponds to wash the amalgam. $\mathrm{H}=$ Furnaces to extract the mercury.

Source: Relation du voyage de la mer du Sud aux côtes du Chili, du Perou, et du Bresil, fait pendant les années 1712, I7I3 \& I714 par M. Frezier, Paris, I732, plate XXII, p. 138.

that more than 200 trapiches were listed. Spaniards owned 58 of them, some were the property of mestizos (those of European and American descent) and mulatos (those of mixed white and black origin), while I60 
of the trapiches were in the hands of indigenous people, both men and women. ${ }^{4 \mathrm{I}}$

These self-employed workers and the trapicheros provoked frequent debates about what should be done with them. While the interests of the mine and mill owners were supported by some local authorities who sought to eliminate the kajchas and the trapiches, the higher colonial authorities sometimes opted for a degree of acceptance because of the tax the kajchas paid to the Crown. Official "tolerance" was therefore essentially a tax-driven policy, imposed against the will of the mines' entrepreneurs, the azogueros.

On the other hand, the detailed daily logbooks of the San Carlos Bank for I 762 recording sales of silver to the bank reveal that the trapicheros numbered almost 500 people and that in relation to I, 500 transactions they accounted for sixteen per cent of total sales (in pesos), while the azogueros accounted for eighty-three per cent. Although the great majority of trapicheros were men, a significant number were women -39 of more than $200 .^{42}$

It is important to emphasize that some documents noted that the "yndios trapicheros" were also employed not only as kajchas, but also as unfree mitayos and free workers. They included the pick-men in the mines. Such sources might exaggerate the intermingling, but the important thing to note is that the people working in the trapiches were associated with workers in the mines and, certainly in a number of cases, they were the same people. ${ }^{43}$

The independent economy of the kajchas and trapicheros in the eighteenth century is a clear example of a practice that had begun in the sixteenth century and which, by the eighteenth century, had helped improved the situation for mineworkers.

\section{THE MITA AS SLAVERY? FROM DEBATE TO ABOLITION IN 1812}

In the final decade of the eighteenth century the mita system had again come close to being abolished. In 1793, Victorián de Villaba, ${ }^{44}$ Attorney General of the Audience de Charcas, wrote his Discurso sobre la mita de Potosi, ${ }^{45}$

4I. See AGI Charcas 48I, no. I9, I763-I769.

42. Archivo Histórico de Potosí, AHP BSC $3 \mathrm{I}_{3}$, for the trapicheros, and AHP BSC 360 for the azogueros. This topic is dealt with in depth in my article in the Hispanic American Historical Review.

43. See AGI Charcas 48 I, no. I9.

44. Born in Aragon, Villaba died in Charcas in I 802. He was Professor of Law at the University of Huesca. He translated fragments of the great work of the famous Gaetano Filangieri (La Scienza della legislazione (1780-1785), 5 vols) and of Lezioni di commercio (1769) by Antonio Genovesi. He was also the author of Apuntes para una Reforma de España, sin trastorno del gobierno monárquico ni la religión (1797). He was appointed Attorney General of the Audiencia de Charcas, where he arrived in I79I.

45. The Discurso sobre la mita de Potosí comprises some twelve folios in four parts, developing the four arguments of the author: (I) the mines of Potosí were not a public work; (2) that even if the work done was public, there was no right to oblige Indians to work; (3) that Indians were not 
using the same title as the abolitionist document written a century earlier by Lagunez. Starting with a religiously inspired motto from St Ambrose ("It is a better thing to save souls for the Lord than to save treasures"), Villaba attacked the mita's existence, arguing that the mines of Potosí could not be regarded as being controlled by the sovereign, and that even if the work done there was for the public good or for the res publica ${ }^{46}$ (the government and the state) no one had any right to oblige Indians to work there. The response was immediate. Potosís highest authority, the Governor Francisco de Paula Sanz and his adviser Pedro Vicente Cañete, ${ }^{47}$ both asserted that, all over the world, since ancient times, mines had been considered to be under the direct dominion of kings, who had duly exploited them $;^{48}$ the Spanish king might therefore exploit the mines directly or indirectly. In the latter case, the king gave his vassals "possession" but not ownership, and for that "concession" received the right of regalia in the form of a proportion of production.

In this great debate between Villaba and Sanz/Cañete, one of the issues discussed was, again, the interpretation of what was public and whether it was rational to continue with a policy that favoured channelling labour to Potosí. Villaba clearly opposed Sanz and Cañete, who, in 1787, wrote a guide to the government of Potosí and a legal code for the mines. ${ }^{49}$

so indolent as it was thought; and (4) that even if they were indolent there was no right to coerce them to work. See the important and pioneering work of Levene, Vida y Escritos de Victorian de Villaba. Villaba's Discurso sobre la mita, the response, and the Contra réplica published by Levene in 1946 are just three pieces of this debate, of which there are thousands of pages in the Archivo General de la Nación and at least thirty-two documents related directly to Villaba (in the Archivo Nacional de Bolivia), many of which are from 1795 and 1796 . This is a wide topic that we will be discussing in another article. For a broad view on Villaba, see José Portillo Valdés, "Victorián de Villava, fiscal de Charcas: Reforma de España y nueva moral imperial”, ANUARIO de Estudios Bolivianos, Archivisticos y Bibliográficos, I 3 (Sucre, 2007). Sanz took over one hundred pages to reply to Villaba's twelve pages.

46. In the early seventeenth century, a number of writers distinguished between coerced and unpaid work on the one hand and obligatory paid work in favour of the res publica on the other (see Zavala, El servicio personal de los indios en el Perú, II, pp. I 8 and $2 \mathrm{I}-22$ ).

47. Francisco de Paula Sanz was administrator of the royal tobacco monopoly in Río de la Plata from 1777 to 1783 and Governor Intendant of Potosí from I 788 to I 8 I 0 . He was born in Málaga in around 1745 and died in December I8ro. Pedro Vicente Cañete was born in Asunción (Paraguay) in $1749-1750$ and died in 1816 . He studied in Santiago, Chile. In $178 \mathrm{I}$, he was designated Adviser to the Governor of Paraguay; later, he became General Adviser and War Auditor to the Viceroy in Buenos Aires and, in 1783 , he was appointed Adviser to the Intendancy in Potosí. 48. The jurist Solórzano suggested, in $\mathrm{I} 647$, that kings had coercive powers over their vassals whenever they believed that this was for the public good. He argued that the members of the republic had to help each other, as if they were members of the same human body. Juan de Solórzano y Pereyra, Política Indiana (Buenos Aires, 1972), I, pp. 267-268.

49. Pedro Vicente Cañete, Guía histórica, geográfica, física, política, civil y legal del Gobierno e Intendencia de la Provincia de Potosí (1787), idem, Código Carolino de Ordenanzas Reales de las Minas de Potosíy demás provincias del Río de la Plata (I794) and Catecismo Real Patriótico (I 8 I I). 
Both men, Sanz and Cañete, thought the mita constituted "the principal centre and support of the welfare of the state" and that without "forced Indians" it would not be possible to make progress. ${ }^{\circ \circ}$

Villaba asserted instead that mining was not a "public" affair controlled by either the nation, or the sovereign because it benefited private actors, namely the mine and mill owners - the azogueros ${ }^{51}$ - and so effectively represented a policy that today we would call "subvention" for a privileged sector and economic group. As a result of this royal concession, the mine and mill owners benefited from the mita, which was designed to "extract the immense wealth of the ramifications of the earth" for the treasury, for the kingdom, and for the splendour and glory of the monarchy. ${ }^{52}$

Villaba's point of view contained another crucial idea. The abundance of money was not the "nerve of the state and the blood of the body politic", because it was a universal commodity ${ }^{53}$ that did not create national happiness. Potosí, said Villaba, remained an example of the fact that "in mining regions, we see only the opulence of the few and the misery of infinite numbers".

A reply to Villaba was published in $1793^{54}$ and some years later, in $\mathrm{I} 796$, the different corporations of Potosí (mainly the mine and mill owners, and the civic authorities) drafted an "Apologetic Representation" expressing their unity in opposition to Villaba, who had published a paper openly calling the mita a tyranny. They attacked Villaba for receiving the support of the Church and accused the priests of a "scandalous" use of indigenous labour, which was why the Church opposed the mita. The corporations also accused the audiencia of meddling in the "exclusive dominion" of the government of Potosí by acting as a "theocratic government". They asserted that Villaba wanted to abolish the mita "to make his name famous in America" and that the real offence was "dismantling the use of the earth's immense riches and impeding the glory and splendour of the Monarchy". Finally, they asserted that "those powerful men that the natives hear, listen to, and faithfully obey [Villaba and the Indian authorities] sought to win them at the cost of the ruin of sovereignty and the royal jurisdiction, which constitutes a state offence and a crime of lèse-patria and lèse-majesté." 55

What was the outcome of this process? The impossibility, once again, of abolishing the mita, the unfeasibility of broadening it, and the paralysis stemming from the Mining Code. However, above all it was a fierce attack

50. Sanz and Cañete in Portillo, "Victorián de Villava”, p. 45 I.

5. "Discurso", in Levene, Vida y Escritos de Victorian de Villaba, pp. xxxi-xxxiii.

52. ABNB Minas I796, I29/I 3 f.2/Iov and f.I35-I7.

53. "Discurso", in Levene, Vida y Escritos de Victorian de Villaba, p. xxxi.

54. Contextación al Discurso sobre la mita de Potosi escrito en La Plata a 9 de Marzo de 1793. Archivo General de Indias. MP Buenos_Aires, v273, MP Libros_Manuscritos, 76 Charcas 676. 55. All this information is taken from the document ABNB Minas $1796, \mathrm{I} 29 / \mathrm{I} 3 \mathrm{f} .2 / \mathrm{Iov}$. 
on the institution of the mita. Villaba, in the first paragraph of his Discurso sobre la mita, insisted that it was "temporary slavery", even if the Indians were not legally slaves. ${ }^{56}$ Nevertheless, Villaba's was clearly a strategy intended to portray the mine owners as slave owners and to delegitimize the mita, and it seems that his approach did indeed affect the number of mitayo workers going to Potosí.

The mita became an important issue over the following decades. The arguments used against it reappeared for example in $\mathrm{r} 802$ in the writings of Mariano Moreno, later a political leader of the Buenos Aires movement for independence. Other radical writers of the period put forward the same arguments. ${ }^{57}$

In I8 Iо, Napoleon Bonaparte's invasion of the Iberian Peninsula prompted a political crisis in Spain, with, as a result, the first sessions of the Cortes de Cádiz - the first Assembly of Spain and the Americas. Representatives repeatedly discussed the situation of the indigenous people. ${ }^{58}$ Those who argued against the mita in Cadiz were well-known individuals who would eventually go on to have long political careers in the independent states of Latin America, men of the same generation as Simón Bolívar, such as José Joaquín de Olmedo, the delegate for Guayaquil, or Florencio del Castillo of Nicaragua and Costa Rica. Although Castillo and Olmedo might not have been familiar with Villaba's writings, they made use of all the arguments generally deployed about the mita, and added some new

56. He made indistinct use of the terms "slave" and "serf" present in Roman law and in the Castilian Partidas. In the classic manual of Roman law, slavery "or" servitude was explained as "an institution [...] by which a man was found subjected against his nature to the domination of another". See Eugene Lagrange, Manual del Derecho romano o explicación de las Instituciones de Justiniano (Madrid, I 870), pp. I00-Iог. The parallel between Villaba and Las Casas is noteworthy. Las Casas wrote an important tract (Sobre la materia de los Indios que se han hecho esclavos) (I552) to prove the unlawfulness of all slavery in the Indies. See David Thomas Orique, "The Unheard Voice of Law in Bartolomé de Las Casas's Brevísima relación de la destruición de las Indias" (Ph.D. dissertation, University of Oregon, 20I I), p. 202.

57. Villaba's influence was present in the radical "Diálogo entre [the Inca] Atahualpa y [the King] Fernando VII en los Campos Elíseos" (I 809), an imaginary work questioning the legitimacy of the Spanish king, in the proposal "in favour of the Indians in general" in the context of the insurgent project of Jiménez de León y Mancocápac, Manuel Victoriano Aguilario de Titichoca, and Juan Manuel Cáceres of I 8 I O-I 8 I I, and in the declarations of Juan José Castelli, one of the leaders of the May Revolution in Buenos Aires in I 8 I o. See María Luisa Soux, "Los discursos de Castelli y la sublevación indígena de I810-18гі", in Carmen McEvoy and Ana María Stuven (eds), La República Peregrina. Hombres de armas y letras en América del Sur I 800-I884 (Lima, 2007); and María Luisa Soux, "Castelli y la propuesta indígena de i 810-18 г 2. Oralidad, discursos y modernidad", in Memoria del Coloquio. El Pensamiento Universitario de Charcas y el 25 de mayo I 809 y I 810 (Sucre, 20I0).

58. Scarlett O’Phelan, “Ciudadanía y Etnicidad en las Cortes de Cádiz”, in Cristóbal Aljovín de Losada and Nils Jacobsen (eds), Cultura politica en los andes (1750-1950) (Lima, 2007); Marie Laure Rieu-Millan, Los Diputados americanos en las Cortes de Cádiz (Igualdad o independencia) (Madrid, I990). 
liberalist-inspired ones of their own. In their view, the mita system was a symbol of the conquest itself and of barbarously feudal legislation. ${ }^{99}$ So abolition of the mita, already a moribund institution in any case, was duly decreed on 2 I October I 8 I 2.

\section{CONCLUSIONS}

We can arrive at a better understanding of the labour system in Potosí, with its continuities as much as its shifts, by closely examining the official policies relating to it, and the discussions concerning those policies. Official policy was, of course, promoted from above, first by the different levels of the Spanish monarchy - whether in Madrid, Seville, Lima, or Potosí - and then modified by the requests at a local level of the mine and mill owners. We can also consider the strategies of workers, who, of course, had to respond to their situation from below.

From the very beginning, in Colonial Spanish America the mita raised the problem of "personal service"; that is to say, the tension between the freedom of the Indians considered as vassals of the Crown and the obligations imposed on them to work in the mines. However, it was equally clear that coercion was based on two commonly articulated reasons for the silver mining industry's economic importance: first, its role in contributing to the public good, and more specifically its contribution through tax to the financial well-being of the monarchy.

The decrease in production, tax yield, and in the number of workers going to Potosí during the seventeenth century gave rise to competing requests and proposals, particularly from the mine and mill owners who championed a new allocation of labour for their enterprises. Their failure to secure their desired reform prompted decades of reports, proposals, and debates between the authorities at the different political levels of the Spanish monarchy between 1692 and 1732 . A hundred years after its implementation, the mita could not be revitalized from its now diminished role, as the mine and mill owners from Potosí had hopefully proposed, although its abolition as advocated by other economic and political groups did not come about either. Potosís mining sector had certainly lost ground, but the Spanish Crown dared not put an end to the industry's privilege because of the resources it still generated. That situation explains why the mita continued despite the changes. For example, in the eighteenth century there were no more than 3,000 workers, compared with I 4,000 at the end of the sixteenth century.

59. José Joaquín de Olmedo, Discurso sobre las mitas de América pronunciado en las Cortes, en la sesión de I2 de Agosto, de I8I2 (London, I8 I2); Alberto Calderón Vega, Florencio del Castillo Villagra y las Cortes de Cádiz. Mociones y proposiciones (Costa Rica, 2010). 
The labour system in the Potosí mines in the eighteenth century emerges as much more complex, the result of intertwined factors. State policies did not revitalize it by increasing the number of mita labourers, but they did decrease taxes and facilitated access to mercury to boost production. For the mine and ore-mill owners the mita was important even after the number of mitayos had decreased considerably, because it was the main mechanism for attracting a significant workforce to Potosí from a population that already had its own land and resources. The workers themselves showed their agency and sought additional gains by exploiting the mines during weekends. The mitayos and mingas could simultaneously be kajchas or have agreements with them. The kajchas were also closely associated with the trapiches, and both of them revealed their empowerment in the mid-eighteenth century, when the Potosí mountain would be divided between the owners of the mines and the kajchas. ${ }^{60}$

In the mita debate at the end of the colonial period, Villaba's discourse in favour of the Indians had much more to do with enlightened concepts of wealth, and humane Christian values. This humanistic perspective was present among the intellectual generation of the late eighteenth and early nineteenth century, who saw the Indians as victims of oppression. By about I 809 , the mita became the symbol of the conquest, with its brutal and feudal legislation, and the obligations of the system represented the absence of freedom for the Indians. The mita became a powerful symbol of America itself in the minds of some, including a number of American assembly members of the Cortes de Cádiz in I 8 I 2. However, the paradox is that the vision of Villaba, who was the most vigorous to defend the Indians, also did most to paint a pitiful picture of their agency, which historians are now trying to overcome.

60. They continued exploiting the ores during the nineteenth century and right up to the r 930 , when cooperatives, still extant, were organized. 